\title{
Reopening Work among Colonial Seamen
}

The bleak records of work among colonial seamen in Europe generated a lively debate at the IPC-TW conference in April 1928. The harshest critique on the pitfalls of work among colonial maritime workers came from Auguste Dumay. He accused the RILU for neglecting the colonial question in the maritime industry and for downplaying the potential impact of colonial maritime workers in both anticolonial and anti-imperial activities. African and Caribbean mariners consituted the majority of the colonial seamen in France, he noted, but most of them were organised in the Féderation Nationale des Laboureurs de la Mer, a 'yellow's union where the communists had no influence at all. Why where there no representatives from Africa or the Caribbean at the conference, he critically asked, and why where there no representatives of the Arab seamen? Dumay was backed in his criticism by George Hardy who urged the IPC-TW and its European sections to focus on work among colonial seamen in European ports. ${ }^{2}$

Dumay's and Hardy's criticism resulted in a reorientation and reorganisation of work among colonial seamen. The task of the revolutionary trade union opposition groups within the national maritime trade unions was to demand that membership was to be based on class only, not race or nationality. Maritime transport workers, who had emigrated to and resided in another country, were to be allowed to join a national union based on the principles of equal rights and equal standing. ${ }^{3}$

However, the IPAC-TW never formulated any directives or issued any instructions on work among colonial seamen after the 1928 Moscow Conference. In part, this might have been due to the total overhaul of communist agitation which followed after the Sixth World Congress of the Comintern in July-August 1928. In late 1927, the Executive Committee of the Comintern (ECCI) had initiated the 'left turn' calling for 'intensified class struggle', warning about 'the treachery of social democracy' and demanded

1 A yellow union is a workers' organisation which is dominated or influenced by the employers and collaborates with the government.

2 "Tätigkeitsbericht des IPAK," in Die 5. Internationale Konferenz der Revolutionären Transportarbeiter, 39, 41.

3 "Tätigkeitsbericht des IPAK," in Die 5. Internationale Konferenz der Revolutionären Transportarbeiter, $55^{-56}$. 
a 'radicalisation of the working class'. According to the new interpretation, bourgeois stabilisation was to give way to a new wave of class struggle due to the believed imminent radicalisation of the working class. Condition for revolutionary work in the colonies and 'semi-colonies', i.e. India and China, were discussed at the Sixth World Congress of the Comintern in 1928. The discussions resulted in a new strategy presented in the Theses on the Revolutionary Movement in the Colonial and Semi-Colonial Countries, better known as the Colonial Theses. ${ }^{4}$

The ultimate objective, the Colonial Theses declared, was the unconditional and complete independence and sovereignty of all colonial people. In contrast to the previous 'United Front'-tactic, the Colonial Theses accused the European social democrats as well as the colonial bourgeoisie for betraying the anticolonial struggle and for seeking rapprochement with the imperialist powers and capitalist governments. Instead, the Colonial Theses stressed the global class-unity of the labouring masses. The Colonial Theses called for the creation of communist parties as well as workers and peasants unions in the colonies, and rejected all collaboration with nationalist movements. At the same time, it criticised the communist parties in the colonial metropolises for their hitherto bleak performance, and for neglecting the existence of hidden racial barriers within the parties. Therefore, it instructed the metropolitan parties to expand their activities into the colonies, to support the formation of colonial centres of trade union activities, and to impel a revolutionary character in the existing peasant movements. ${ }^{5}$

However, as Neil Redfern has underlined, neither before nor after the 1928 Colonial Theses did the Comintern break with its Eurocentric analysis of world affairs. ${ }^{6}$ Instead, the Colonial Theses proclaimed a closer unity between revolutionary movements in the colonies and the Soviet Union, and underlined the need for an alliance between the Soviet Union, the Western industrial proletariat and the oppressed masses in the colonial and semi-colonial countries. $^{7}$

4 See further Fredrik Petersson, "The 'Colonial Conference' and the Dilemma of the Comintern's Colonial Work, 1928-29," in Communist Histories, Volume I, ed. Vijay Prashad (New Delhi: LeftWord Books, 2016), 72-127.

5 See further Petersson, "The 'Colonial Conference,", and Fredrik Petersson, "Imperialism and the Communist International," Journal of Labor and Society 20, no. 1 (2017), 23-42.

6 Neil Redfern, Class or Nation: Communists, Imperialism, and Two World Wars (London: I.B. Tauris, 2006).

7 Edward T. Wilson, Russia and Black Africa before World War II (New York and London: Holmes and Meier, 1974), 166-167, 171-172. 
Communist agitation and propaganda among Asian maritime transport workers in Europe had yielded few lasting results by 1928. Work had been concentrated to British ports as most of the Chinese and Indian seamen were employed on British vessels. However, due to the weakness and at best lukewarm interest of the Minority Movement, communist agitation among Asian seamen had been shallow if non-existing. George Hardy, at the 1928 Moscow Conference, had heavily criticised the pitiful performance of the Minority Movement. Returning to England after the conference, Hardy drafted a blueprint for future work in Britain, underlining the necessity to focus on colonial seamen. More than 140,000 registered African and Asian seamen resided in Britain, he noted, and 26 percent of seamen on British ships were Asian workers. Hardy's proposal for future work was radical and placed the colonial seamen as the prime target group for the projected red seamen's union, see Chapter 3.1.1. In contrast to the existing unions, the new red union was to open sections for Chinese and Indian seamen "which would add to the power of our colonial fellow workers, especially when they cannot organise legal organisations in their own countries." Hardy was fully aware of the 'revolutionary' antidiscriminatory, anti-racist and anti-segregationist tenor of his blueprint: "This would cause such agitation among British seamen that would have great political value and break down their prejudices as well as enabling us to use such a union for practical colonial work."

Nothing happened. Hardy himself was unable to push for his ideas as the RILU transferred him to Shanghai to head the PPTUS apparatus in early 1929. ${ }^{9}$ The Minority Movement, in turn, rejected the idea of forming a red seamen's union. Britain remained a peripheral arena for communist agitation among colonial maritime transport workers. Although there was an ongoing radicalisation among colonial seamen in British ports, resulting among others in the establishment of the Indian Seamen's Union in London and an association for colonial seamen in Cardiff, their links to the Minority Movement and its seamen's section were shallow. ${ }^{10}$ Neither had the Minority Movement or its

8 [George Hardy,] Tasks and Position of Seamen in the British Shipping Industry [ca. 1928], 534/5/194, 165-168, RGASPI.

$9 \quad$ Fowler, Japanese and Chinese Immigrant Activists, 76.

10 See further Sherwood, "Lascar Struggles Against Discrimination in Britain;" Christian Høgsbjerg, "Mariner, Renegade and Castaway: Chris Braithwaite, Seamen's Organiser, Socialist and Militant Pan-Africanist," Race \& Class 53 (2011): 36-57; Featherstone, "Harry O'Connell," 71-87. 
seamen's section been active on establishing ship cells on board British vessels, not to speak about sea cells in British ports, for which it was criticised by Albert Walter. ${ }^{11}$

Work among colonial seamen ended in a cul-de-sac in Britain and had to be concentrated elsewhere. Three possible locations were at hand for the IPACTw: Hamburg, Marseille and Rotterdam. Each of these ports had its potentials but also drawbacks. The Hamburg Interclub was the best organised one but the port was not a major destination for British shipping. The Rotterdam Interclub, on the other hand, had reported major difficulties in reaching out to the crew on British vessels. Marseille, in turn, was not a target of British shipping and the Interclub had a poor record on work among colonial seamen. After evaluating the pros and cons of the different options, the IPAC-TW headquarters decided to shift its work among colonial seamen to Hamburg by detaching Asian functionaries to the Hamburg Interclub.

The first to arrive in Hamburg was the Indian comrade Silva. He started to work at the Interclub in February 1928. At first, the Interclub functionaries were extremely positive about his work. ${ }^{12}$ However, Silva's job ended prematurely after only one month as he became ill and decided to move to Berlin. Work among Indian seamen ceased as there was no replacement for him. ${ }^{13}$ A new attempt to start work among Asian seamen in Hamburg was made in September 1928. Achkanov informed Walter about sending a Chinese seaman from Hong Kong to work in Hamburg. ${ }^{14}$ However, it seems as if nothing came out of these plans and there are no references about work among Chinese or Indian seamen for the rest of the year in the monthly reports of the Interclub. The first push for work among colonial seamen in Hamburg had ended in a cul-de-sac, too.

Opening a New Chapter: Work among Black Seamen

While the Comintern had debated at length about the prospects and conditions for the radicalisation of the working class in India and China at its world congresses in the early $1920 s,{ }^{15}$ the Atlantic world and especially sub-Saharan

11 See, among others, Internationales Hafenbüro Hamburg, Bericht März 1929, 534/5/210, 46-47, RGASPI.

12 Internationales Hafenbüro Hamburg, Bericht Februar 1928, 534/5/201, 12, RGASPI.

13 Internationales Hafenbüro Hamburg, Bericht März-April 1928, 534/5/201, 23, RGASPI.

14 NN [probably Achkanov] to Walter, September 1928, 534/5/201, 56, RGASPI.

15 John P. Haithcox, "The Roy-Lenin Debate on Colonial Policy: A New Interpretation," The Journal of Asian Studies 23, no. 1 (1963): 93-101. 
Africa remained a blanc spot on the world-map of the forthcoming World Revolution. Although John Reed vehemently called upon the comrades to focus on the downtrodden black population in the USA in a famous speech at the Second World Congress of the Comintern in Moscow in 1920, ${ }^{16}$ the Comintern was slow in developing a distinctive strategy for agitation and propaganda among the black working class in the Atlantic world. At first, the Comintern addressed only the conditions of the black working class in the USA and in South Africa in the so-called 'Negro Theses' of 1922 and 1924; the situation in the African colonies, in the Caribbean or in Latin America (especially Brazil) remained marginal if recognised at all. ${ }^{17} \mathrm{~A}$ similar case was the 1920 Theses on the National and Colonial Question that heavily criticised British and French imperialism in sub-Saharan Africa and the Caribbean, and had placed the metropolitan parties in the West in the forefront for orchestrating anticolonial and anti-imperial agitation and propaganda. ${ }^{18}$ However, the biggest dilemma for the architects of the Communist anticolonial doctrine was an apparent lack of left-wing militant agents for leading the anticolonial struggle in the African and Caribbean colonies; those existing were not workers but black intellectuals and so-called 'petty-bourgeois anticolonial nationalists' who rather adhered to radical pan-Africanism as their ideology than communism. ${ }^{19}$

Initially, Moscow's tactical considerations included a temporary alliance between the communists and the anticolonial nationalists in colonial and 'semi-colonial' countries as stipulated in the Lenin's thesis on the National and Colonial Question. ${ }^{20}$ In contrast to the social democrats and the Labour and Socialist International (LSI), the rhetoric of the Comintern and the

16 See John Reed, "America and the Negro Question," Minutes of the Second Congress of the Communist International, Fourth Session 25 July 1920, available at https://www.marxists. org/history/international/comintern/2nd-congress/cho4.htm\#v1-p121.

17 Holger Weiss, Framing a Radical African Atlantic: African American Agency, West African Intellectuals and the International Trade Union Committee of Negro Workers (Leiden: Brill, 2014), 57-62.

18 "Theses of the Second Congress of the Communist International on the National and Colonial Questions," in Elie Kedourie (ed.), Nationalism in Asia and Africa (London: Routledge, 2013).

19 Wilson, Russia and Black Africa; Heinz Deutschland, "Zu den Beziehungen zwischen der RGI und den sich formierenden Gewerkschaften in Tropisch-Afrika," in Die internationale Gewerkschaftsbewegung zwischen den beiden Weltkriegen. Internationale Tagung der Historiker der Arbeiterbewegung. 16. Linzer Konferenz 1980, ed. Helmut Konrad (Wien: Europaverlag, 1982), 138-147; Jonathan Derrick, Africa's 'Agitators'. Militant AntiColonialism in Africa and the West, 1918-1939 (London: Hurst, 2008).

20 D. Bing, "Lenin and Sneevliet: The origins of the theory of colonial revolutions in the Dutch East Indies," New Zealand Journal of Asian Studies 11, no. 1 (2009): 153-177. 
communists was in its essence anti-imperial and anti-colonial, calling for the national independence of the colonies and fully backing the struggle against capitalist and colonial exploitation. ${ }^{21}$ In the USA, the anticolonial and antiracial sentiments of the Bolsheviks and the Comintern were embraced by black radical activists such as Cyril Briggs, Otto Huiswoud and Richard B. Moore, who joined the Communist Party, and was articulated by radical black organisations such as the African Blood Brotherhood and the American Negro Labor Congress. ${ }^{22}$ Most importantly, the rationale of communist doctrines positioned US black radicals-cum-communists in the vanguard of anticolonial and anti-imperial agitation and propaganda in the Black Atlantic. However, the ultra-left turn and the introduction of the 'Class-Against-Class'-doctrine of the Comintern and the RILU in 1928 terminated any existing cooperation with black radical nationalists. Instead, radical international proletarian solidarity demanded the cooperation between the black and white working class and the new doctrine called for a new approach for the radicalisation of workers throughout the Black Atlantic. This was materialised in the establishment of the International Trade Union Committee of Negro Workers of the R.I.L.U or ITUCNW-RILU in July 1928; its key propagator being the African American communist trade union organiser James W. Ford (1893-1957). ${ }^{23}$ Best known for being the mastermind for the communist push into the Atlantic world, his activities propelled the IPAC-TW to reframe its work among colonial seamen and to put the "coloured" or black seamen on its agenda.

\subsection{The Red Push into the Black Atlantic}

James W. Ford joined the CPUSA in 1926 and became an industrial organiser in the Southside of Chicago. Thereafter, he rapidly rose in the party hierarchy, although his chief engagement was in the Trade Union Educational League (TUEL), the US section of the RILU. One year later, he was elected to the District

21 Fredrik Petersson, "The Labour and Socialist International and 'the Colonial Problem': Mobilisation by Necessity or Force, 1925-1928," in The Internationalisation of the Labour Question: Ideological Antagonism, Workers' Movements and the ILO since 1919, eds. Stefano Bellucci and Holger Weiss (London: Palgrave MacMillan, 2020), 119-144.

22 See further Minkah Makalani, "Internationalizing the Third International: The African Blood Brotherhood, Asian Radicals, and Race, 1919-1922", The Journal of African American History 96, no. 2 (2011): 151-178; Jacob A. Zumoff, The Communist International and US Communism, 1919-1929 (Leiden: Brill, 2014).

23 Holger Weiss, "Framing Black Communist Labour Union Activism in the Atlantic World: James W. Ford and the Establishment of the International Trade Union Committee of Negro Workers, 1928-1931," International Review of Social History 64, no. 2 (2019): 249-278. 
Party Committee and Industrial Committee of the Trade Union Committee of Chicago. Having experience of trade union work, he was nominated as US delegate to the Fourth World Congress of the RILU, and arrived in Moscow in March 1928. At the RILU Congress, he was selected to its Executive Committee. Ford stayed in Russia for the next nine months and attended the Sixth World Congress of the Comintern, held from July to September $1928 .{ }^{24}$

Ford's sojourn in Moscow opened a new chapter in his own life as well as in communist engagement with black workers throughout the Atlantic world. The engagement of the RILU with the Black Atlantic had hitherto oscillated between non-existence (Sub-Saharan Africa and the Caribbean) and, at most, a lukewarm attitude (USA and South Africa). For the RILU, its Fourth World Congress marked the beginning of a new era in the approach towards the Black Atlantic. This was mainly due to the intervention of Ford at the congress. Ford highlighted the need for revolutionary work in Africa and criticised the RILU and its sections for underestimating, if not totally neglecting, work among the black workers in the Atlantic world. However, his main attack was on white chauvinism that existed among the working class. He charged the RILU to change its policy towards the so-called 'Negro Question': The suppression of the black population in the USA and South Africa and their struggle for political rights and self-determination. ${ }^{25}$ Ford repeated his criticism at the Sixth World Congress of the Comintern in August 1928 where he attacked the Comintern and the metropolitan communist parties for neglecting the plight of the oppressed masses in the Black Atlantic. Even worse, Ford claimed that neither the Comintern leadership nor the metropolitan parties had fully understood the global importance of activating the oppressed masses throughout the Black Atlantic. ${ }^{26}$

Ford's criticism at the RILU World Congress started a process that culminated in the foundation of a new radical organisation for black workers a few months later. Concurrent with the Sixth World Congress of the Comintern, the Executive Committee of the RILU summoned for a separate meeting in July 1928, and decided to establish the International Trade Union Committee

24 James Ford, Life and activities, dated 20.4.1932, RGASPI 495/261/6747 [hereafter Ford, Life and activities (1932)].

25 "Antrag zur Organisierung der Neger", in Protokoll über den 4. Kongress der Roten Gewerkschafts-Internationale abgehalten in Moskau vom 17. März bis 3. April 1928 (Moscow: Rote Gewerkschafts-Internationale, 1928), 479; James W. Ford, Negro Work in America, 11.5.1928, 495/155/59, 1-14, RGASPI.

26 Extract from Ford's speech at the Sixth World Congress of the Comintern, published in Inprecor 8, no. 44 (3 August 1928): 772-773. 
of Negro Workers of the R.I.L.U. or ITUCNW-RILU ${ }^{27}$. The objective of the ITUCNW-RILU was to reach out and agitate among the black workers throughout the Black Atlantic so that they would join the labour unions. The goal was either to open the unions for black workers or, if this was not possible due to racial discrimination and barriers within the unions, to establish independent black ('Negro') trade unions. Equally important was the establishment of a global network, i.e., "the work of setting up connections with the Negro workers of the whole world and the unification of the wide masses of Negro workers on the basis of class struggle."28

Ford had hitherto concentrated on trade union work Chicago and had no reference to maritime transport workers. Consequently, he had not participated at the Fifth Conference of Revolutionary Transport Workers in April 1928. However, his ambition to embrace all black toilers in the radar of the ITUCNW-RILU made him aware of the plight of the black seamen. The trigger was a disaster at sea when the British passenger liner SS Vestris sank about 200 miles off the coast of Virginia on 12 November 1928, resulting in the loss of 111 people. The accident was due to a fatal neglect of security on board and many of the drowned were black mariners. The disaster made headlines on both sides of the Atlantic although it probably was Ford's article in the International Press Correspondence in January 1929 that caught the attention of the leading comrades at the Comintern and RILU headquarters. ${ }^{29}$

One who definitively had noted Ford's activities in Moscow was IPAC-TW Secretary Achkanov who called him for a meeting together with representatives of the RILU and Japanese seamen at his bureau on 14 December 1928. Two topics were on the agenda, namely the organisation of Japanese and black

27 The abbreviation ITUCNW-RILU is used as to distinguish this organisation with two other ones, the International Trade Union Committee of Negro Workers established at the July 1930 conference in Hamburg and the so-called 'Negro Bureau' of the RILU (RILU Negro Bureau), the latter organisation being the successor of the ITUCNW-RILU. See further Weiss, Framing a Radical African Atlantic.

28 Resolution of the Executive Bureau of the RILU on the Organisation of the International Trade Union Committee of Negro Workers, 31.7.1928, 534/3/359, 1-6, RGASPI; On the RILU International Bureau of Negro Workers, copy, no date [handwritten add: 1928], 495/ 155/53, 1, RGASPI. See further Minkah Makalani, In the Cause of Freedom: Radical Black Internationalism from Harlem to London, 1917-1939 (Chapel Hill: University of North Carolina Press, 2011), 151; Hakim Adi, Pan-Africanism and Communism: The Communist International, Africa and the Diaspora, 1919-1939 (Trenton: Africa World Press, 2013), 42 46; Weiss, Framing a Radical African Atlantic, 130-133.

29 [James] Ford, "The "Vestris" Disaster and Coloured Seamen," Inprecor 9, no. 4 (18.1.1929): $63-64$. 
("Negro") seamen. ${ }^{30}$ While Josephine Fowler has scrutinised the former topic, the latter one has hitherto not been analysed in academic texts.

The Vestris disaster together with the December 14-meeting were cataclysmic for the IPAC-TW. The 'coloured' or black seamen had hitherto played a marginal if any role in the strategic deliberations in Moscow and neither had the Port Bureaus and Interclubs paid any attention on them. Ford and the ITUCNW-RILU started a campaign after Vestris disaster to attract the attention of the exploitations of black seamen. ${ }^{31}$ It is likely that Achkanov had conceived the campaign although certainly not initiated it. On the other hand, Achkanov noted in his report to the RILU Executive Bureau in early January 1929:

$[T]$ he question of the organisation of the coloured seamen, especially in view of the unceasing efforts of the shipowners to gradually substitute them, as the lower paid and unorganised, for the white crews on the ships of all countries, which circumstances drew the attention of the Fifth Conference of Revolutionary Transport Workers. ${ }^{32}$

While this summarised Dumay's and Hardy's criticism at the 1928 Conference, the beginning of work among black seamen was set in the aftermath of the Vestris disaster when the New York Interclub started a campaign for organising black seamen. The IPAC-TW itself was prepared to take a leading role, Achkanov assured, and noted that it was planning to call for a conference of colonial seamen to discuss the creation of organisation amongst them. ${ }^{33}$

It is likely that the idea of summoning a conference for colonial seamen had been raised at the meeting on December 14; perhaps it even was the brainchild of James W. Ford. The task of the ITUCNW-RILU had been to call for a conference of black workers, and it is not farfetched to argue that the planned conference for colonial seamen was to be organised in tandem with the ITUCNWRILU conference. The planned conference, at least, was on top of the agenda when Ford embarked on a tour to Western Europe in January 1929. Travelling via Cologne, Brussels, Paris, Berlin and Hamburg, he had discussions with leading party members in Belgium, France and Germany about their work among black residents as well as their links to the African and Caribbean colonies.

$30 \quad$ Fowler, "From East to West," 110-111.

31 James W. Ford, "Report on the Work of the International Trade Union Committee of Negro Workers of the R.I.L.U.," The Negro Worker, Special Number (1st November 1930): 7 .

32 Achkanov, Report on activities 1928, 534/5/207, 12, RGASPI.

33 Achkanov, Report on activities 1928, 534/5/207, 12, RGASPI. 
Back in Moscow in mid-February 1929, Ford sent a detailed report about his trip to the ECCI. ${ }^{34} \mathrm{He}$ also sent a detailed report to the Negro Bureau of the Eastern Secretariat of the Comintern, ${ }^{35}$ including a detailed list of recommendations for its future work. On top of the list was his intention to send an official letter to the French and German Parties outlining the special tasks of both the Negro Bureau and the two parties. Second, a special letter was to be sent to the British Party, highlighting their task in concentrating on the work among the coloured seamen, on work in Africa and the other colonies as well as to work among the black population in England. ${ }^{36}$

Ford's specific attention on the black seamen raises several questions. First, work among maritime transport workers, organised as well as unorganised ones such as the black mariners, was the task of the IPAC-TW, not of the ITUCNW-RILU. Was Ford breaking new grounds for his organisation, was he fishing in another RILU-unit's water or was he acting on mandate of the IPACTW? Second, who was to organise the daily work among black mariners if not the Port Bureaus and Interclubs rather than the ITUCNW-RILU as the latter unit was nothing else but an office in the RILU-building in Moscow? Third, were black seamen to be organised within existing unions or in new (red?) unions to be formed on a colour-basis?

A hint about Ford's agenda regarding work among black seamen is found in his discussions in Hamburg. After his meeting in Berlin in late January 1929, Ford travelled to Hamburg where made a speech at the Interclub's 'LeninLiebknecht Celebration' and had a meeting with key communists in Hamburg, including the Secretary of the KPD-Hamburg Ernst Grube ${ }^{37}$, Albert Walter

34 James W. Ford, Report on trip in interest of the work of the International Trade Union Committee of Negro Workers of the RILU and the Negro Bureau of the Comintern, and the Meeting of Executive Committee of the League Against Imperialism, copy, no date [probably written after 14.2.1929], 495/155/70, 62-68, RGASPI, copies also in 534/3/45o, 53-59, RGASPI, and 495/155/78, 34-49, RGASPI.

35 The Negro Bureau of the Eastern Secretariat was headed by British Communist Robin Page Arnott and had been established in the aftermath of the Sixth World Congress of the Comintern. Its task was to instruct the European communist parties about their work in the African and Caribbean colonies. See further Weiss, Framing a Radical African Atlantic, 123-124, and Petersson, "The 'Colonial Conference', 87-92.

36 (Ford), Recommendations to Negro Bureau, copy, no date [reference in the document to Ford's report, i.e., the document was written in February 1929], 495/155/70, 61, RGASPI. Weiss, Framing a Radical African Atlantic, 146, 150. The letter to the CPG B is also discussed in Sherwood, "The Comintern," 140.

37 Ernst Grube (1890-1945) was 'Polleiter' (Politischer Leiter) of the KPD Wasserkante in Hamburg from 1928 to 1930, see further "Ernst Grube," in Hermann Weber/Andreas Herbst, Deutsche Kommunisten, 326. 
and a certain Comrade "Deadman"38. The German comrades presented Ford a detailed overview of the working conditions in the Hamburg harbour and the potentials for work among foreign seamen. Currently, they stated, work among Chinese and Indian maritime transport workers was usually easy as they had their own sub-groups and restaurants where the communists could reach them and distribute propaganda leaflets. African seamen were more difficult to reach as they were not organised and had no special designated meeting places or clubs. On the other hand, Hamburg was one of gateways to the Atlantic world and Walter's global courier system could easily be expanded to African ports. Not only that, Grube and Walter also suggested that they could work out some concrete plans for smuggling Africans out of the continent. Last, but not least, Ford considered it advisable to have a "Negro comrade" assigned for work at the Hamburg Port Bureau. ${ }^{39}$

\subsection{Hamburg as the Centre for Colonial Work}

Achkanov was certainly aware of Ford's report as its copies circulated in the Comintern and RILU headquarters. However, what Ford might not have been aware of is the existence of a memorandum on his meeting in Hamburg. Put together, the December 14-meeting as well as the memorandum of the Hamburg meeting shed some light on the revision and readjustment of IPACTW engagement in Western Europe.

The revision projected a total reorganisation of work among colonial and 'coloured' seamen. In late January 1929, the IPAC-TW headquarter sent an urgent message to Walter, informing him about the planned new strategy. Work among 'coloured' seamen was to become the main focal area of work; an official statement was planned to be made at the next plenary meeting of the IPAC-TW Bureau. Walter was ordered to send in a statistical report on the numbers of colonial and "coloured" seamen visiting Hamburg. Also, the IPAC-TW headquarters asked for Walter's opinion on the feasibility to establish a special 'corner' or section for the 'coloured' and colonial seamen at the Interclub. Likewise, Walter was urged to contact the Indian Seamen's Union in London for material to be displayed at the Interclub. ${ }^{40}$

38 In fact, "Deadman" was the communist member of the Hamburg parliament Friedrich Dettmann (1897-1970), as noted in Walter's minutes of the meeting, see Sitzungsbericht, no date [stamped 12.2.1929], 534/5/210, 28, RGASPI. Dettmann was, among others, editor in chief of the communist semiweekly newspaper Hamburger Volkszeitung, see further "Friedrich Dettmann," in Hermann Weber/Andreas Herbst, Deutsche Kommunisten, 185.

39 Ford, Report on trip [ca February 1929], 495/155/70, 65, RGASPI.

$40 \mathrm{NN}$ to Walter, Russian original letter dated 30.1.1929, German version undated, 534/5/210, 18-19, RGASPI. 
A few weeks later, the IPACT-TW headquarters received Walter's memorandum on his meeting with Ford. The main issue on the agenda, Walter informed, was the current state of affairs with regards to work among 'coloured' and colonial seamen. So far none or not much agitation, was the answer, although Walter presented a detailed description of places and spots colonial seamen visited during leisure time spent ashore. While there existed several bars and restaurants frequented by Chinese and Indians, no such localities existed for black seamen. Neither had Grube or Walter any idea about the number of the resident black/African population in Hamburg but they promised to ask the communist student association to make an inquiry about this matter. Most importantly, however, was Grube's and Walter's critical remark that Hamburg was not an ideal place for work among 'coloured' seamen as only a few steamers with black crew members called at the port. Rather, the noted, work should be concentrated to Antwerp as both the Belgian Lloyd's steamers to the Congo and most of the French steamers calling at the port were manned with black seamen. On the other hand, the drawback with Antwerp was that agitation among 'coloured' seamen had hitherto been almost nil. Interestingly, the critical deliberations on the prospects for work in Antwerp and Hamburg were missing from Ford's report. ${ }^{41}$

Nevertheless, Walter assured that it was not impossible to start work among 'coloured' seamen in Hamburg. What he needed were addresses of black seamen in other ports; after receiving them, he could organise communications with Africa and the Caribbean. His first dispatch, he informed, was to include the forthcoming 'Action Programme' of the 'RILU Negro Bureau'.42

The last item on the agenda was the forthcoming 'Negro Conference', the organisation of which had been Ford's main objective. Interestingly, and what hitherto has not been recognised in academic research, Ford originally planned to summon the conference to Hamburg [instead of London, as previous research has claimed]! According to Walter's memorandum, Grube had assured Ford that the local party leadership would take care of the practical arrangements for the conference. ${ }^{43}$

41 Sitzungsbericht, no date [stamped 12.2.1929], 534/5/210, 28, RGASPI.

42 Sitzungsbericht, no date [stamped 12.2.1929], 534/5/210, 28, RGASPI. The brochure Walter referred to was the Trade Union Programme of Action for Negro Workers, issued by the 'International Trade Union Committee of Negro Workers of the RILU' but published by the 'International Propaganda and Actional [sic!] Committee of Transport Workers'.

43 Sitzungsbericht, no date [stamped 12.2.1929], 534/5/210, 29, RGASPI. On the plans for organising the 'Negro Conference', see Weiss, Framing a Radical African Atlantic. 
Walter's memorandum set the stage for the next phase of the reorganisation process. The IPAC-TW headquarters informed Walter that Ford still regarded Hamburg to be the best place for work among 'coloured' seamen and had pushed for an immediate start of operations. Therefore, Walter was relieved from all other duties apart from his engagement with the Interclub as to enable him to concentrate on 'international' work among seamen and harbour workers. His prime task was to develop the outreach to 'coloured' seamen. ${ }^{44}$

Walter's investigation on conditions for working among 'coloured' seamen in Hamburg seemingly confirmed Ford's positive vision of Hamburg. Black seamen predominated the crew on the British shipping company Elder Dempster, of which on average four steamers arrived each month with about 55 black mariners. In addition, some French liners employed black stokers. Altogether, Walter calculated that perhaps 100 to 120 black seamen would monthly visit the Interclub. However, black seamen constituted only a small proportion of all colonial seamen visiting Hamburg each month. Indian seamen, predominantly employed on British steamers, counted 6oo to 80o; Chinese seamen, mainly on Dutch and German vessels, 250 to 300; as well as about 500 Brazilian seamen. In total, some 1,200 to 1,500 colonial seamen visited Hamburg each month, Walter underscored, although and agitation and propaganda work among them had hitherto been neglected. ${ }^{45}$

\subsection{Readjustment in Practice: Closing Activities in Bordeaux and Rotterdam}

Ford's intervention had paid off: The organisation of black workers was given top priority by the RILU. Unfortunately, little is known about the discussions at the RILU headquarters in winter 1928/1929. Their outcome, however, deeply affected the organisational setup of the IPAC-TW. The core issue, it seems, concerned the funding the international apparatus of the IPAC-TW, and this turned out to be a major challenge. The economic resources of the headquarters were limited and most external units relied heavily on monthly instalments from Moscow.

The adjustment to the new strategy gave rise to drastic revisions in the transfer of funds from Moscow. Already in September 1928, the IPAC-TW headquarters had informed Dumay about cutting the funding for the Latin Secretariat. The reduced budget deeply affected its operations. Work among Italian seamen in Marseille had to be scaled down, the publication of the

\footnotetext{
44 NN [Achkanov?] to "Werter Genosse" [probably Walter], 26.2.1929, 534/5/210, 26-27, RGASPI.
}

[Walter?] an das Sekretariat des IPAKT, Hamburg 25.2.1929, 534/5/210, 31, RGASPI. 
Le Travailleur International des Transport had to be suspended, and work in Dieppe, Le Havre and Rouen had to be terminated. ${ }^{46}$ Similar information about drastic reductions reached the comrades in Rotterdam in February $1929 .{ }^{47}$

Worse was to come. In spring 1929, the IPAC-TW headquarters informed all affiliated units about its constrained economic situation. Funds were running dry and could barely cover the expenses for campaigns and publications, headquarters declared. Therefore, the IPAC-TW secretariat instructed all sections and revolutionary opposition groups to generate their own funding by collecting membership dues "to be paid by each and every revolutionary transport worker." ${ }^{8}$ As part of the budgetary adjustments, the Port Bureaus in Bordeaux, Copenhagen and Rotterdam were to be closed by April 1929, headquarters informed Walter:

[T] hings have changed to the detriment of our general position and we are now compelled to suspend the publications in German, Spanish and Arabic and also to liquidate the Port Bureaus [...] Of course you will understand that only exceedingly difficult circumstances could have forced us to take such a step. ${ }^{49}$

Jensen in Copenhagen, in turn, received a longer explanation: "The Rotterdam Club, which as you know is not only a very significant club in itself, but is exceedingly important in view of the $5^{\text {th }}$ Conference decision on organising a Unity Committee of Dockers and Seamen of the North Sea, will have to be completely closed down. ${ }^{50}$ Dumay, too, received a similar notification at the end of March 1929: The Latin Secretariat was to concentrate its operations to the Marseille Port Bureau and Interclub, to publish Le Cri des Marins, and to focus on strengthening the Federation Unitaire des Marins. ${ }^{51}$

46 Revised budget for the Latin Section, [handwritten add: 13.IX.28], 534/5/205, 11, RGASPI.

47 NN to "Dear Comrade," Rotterdam 11.2.1929, 534/5/207, 56, RGASPI, containing a complaint about the lowered budget.

48 IPAC-TW Bureau to all TU Organisations and Groups Affiliated to the TWIP\&AC, no date [ca March/April 1929], 534/5/207, 142-143, RGASPI. Similar directives were distributed in French, German, and Spanish.

49 NN to "Dear Friend," no date [ca. March 1928], 534/5/207, 128, RGASPI. The recipient of the letter was most likely Albert Walter as reference is made in the letter that the recipient was to contact "our friend in Berlin." A similar letter in German is filed in 534/5/207, 126, RGASPI.

50 [Achkanov?] to Jensen, no date [April 1929], 534/5/211, 22, RGASPI.

$5^{1} \quad$ NN to Dumay, no date [Russian original text dated 31.3.1929], 534/5/207, 130, RGASPI. 
Moscow's order created an outcry, the Dutch Party protested vehemently. ${ }^{52}$ All in vain, the three Port Bureaus were liquidated. (On the intricate process of closing the Copenhagen Port Bureau and Interclub, see Chapter 3.2.2.) More successful was the intervention to rescue operations in the newly opened Interclub in Bremen as the comrades in Hamburg assured that they had enough funds at their disposal to support the activities in Bremen. ${ }^{53}$ Moreover, the Esbjerg Interclub managed to survive, as it was not depending on external funding.

Apart from Marseille, the only European unit unaffected by Moscow's readjustment process was the Hamburg Port Bureau. Achkanov notified Walter about the impending cuts and liquidations of the Port Bureaus. The Hamburg Interclub was the only exception, and Achkanov ordered Walter to muster all efforts to support work among American, British and French seamen. This was of utmost importance, Achkanov highlighted, as the organisation of revolutionary trade union organisations made good progress in France, where the Federation Unitaire des Marins already counted some 4,0oo members, and in the USA, where the Marine Workers Progressive League was to be transformed into a red union in near future. The only disappointment was Britain where the Minority Movement still rejected the plans for a red seamen's union. ${ }^{54}$ However, additional funding was not to be expected and the RILU Berlin Bureau declined Walter's application for extra funding to cover for the total renovation and extension of the premises at Rothesoodstrasse. ${ }^{55}$

\section{4 "Work among Black and Colonial Seamen is Making Steady Progress"}

Work among black seamen started at the Hamburg Interclub in April 1929. Activities were at first restricted by the ongoing total renovation of the building at Rothesoodstrasse. ${ }^{56}$ Then, with the opening of the new and extended premises in June, an increased number of 'coloured' seamen started to visit

$5^{2}$ See letter from Communist Party Holland to the RILU, 5.4.1929, 534/5/207, 135, RGASPI.

53 NN "an das IPAK der Transportarbeiter," Betrifft Seemannsklub Bremen, 11.3.1929, 534/5/ 207, 113, RGASPI; Note (in German), NN to NN, no date, 534/5/207, 152, RGASPI. The author of the letter was a functionary at the Hamburg Interclub, the recipient most likely the RILU Berlin Bureau.

54 Achkanov to "Lieber Freund" [Walter], no date [Russian version dated 21.3.1929], 534/5/ 210, 41, RGASPI.

55 NN [probably Max Ziese] to "Lieber Freund," no date, 534/5/207, 187, RGASPI. It is likely that this is an internal communication from Berlin to Hamburg as the author asks the recipient to inform Walter about the decision. Similar information in NN to "Lieber Freund," 26.8.1929, 534/5/207, 191, RGASPI.

56 Internationales Hafenbüro Hamburg, Bericht April 1929, 534/5/210, 51, RGASPI. 
the Interclub. ${ }^{57}$ Initially, the IPAC-TW suggested that a special corner for the 'coloured' seamen to be designated at the club but Walter declined due to lack of space. Instead, he proposed to establish such a corner in the new premises of the club. ${ }^{58} \mathrm{~A}$ few months later, Achkanov reminded Walter about the importance of such a corner. ${ }^{59}$ This time, the functionaries of the Interclub questioned the idea of confining black and colonial seamen to a special corner or section. In their mind, one should not create artificial barriers, as this would imply that the Interclub was segregating white and non-white mariners. All comrades here, they underlined, were against the plan, and even the 'coloured' seamen preferred to sit with their white mates instead of occupying a corner by themselves. ${ }^{60}$ The plan for the special corner was for the time being shelved only to be reintroduced by Ford when he started his work in Hamburg in late 1930, see Part Three.

The immediate impact of communist agitation and propaganda among black seamen is difficult to assess. Visiting the Interclub and spending an evening did not result in them joining the revolutionary trade union opposition. Perhaps they did so when returning home but little if any information about this reached Hamburg. It is even likely that this was not the case in 1929; if they resided in the United Kingdom or were British colonial subjects, they would still face the stiff racist and discriminatory rules of membership in the British maritime unions. Neither was the seamen's section of the Minority Movement a trade union per se. Walter had to admit that work among black seamen was slow to start - the Interclub lacked comrades who were suitable for the job and, consequently, only a few of them visited the Interclub and its outreach to the black Atlantic was almost nil.61

However, far better conditions prevailed for work among Chinese seamen in Hamburg. At first, the Interclub functionaries were only capable to approach them when they visited a British or Dutch vessel. ${ }^{62}$ The arrival of a Chinese comrade in October 1929 set the stage for special work among Chinese mariners. ${ }^{63}$ The Chinese comrade in Hamburg was Liao Chenghzi who worked as a special functionary at the Interclub. His main task was to produce communist leaflets in Chinese and to develop an underground communication network

57 Internationales Hafenbüro Hamburg, Bericht Juni 1929, 534/5/210, 65, RGASPI.

58 [Walter?] "an das Sekretariat des IPAKT," Hamburg 25.2.1929, 534/5/210, 31, RGASPI.

59 NN [Achkanov?] to "Lieber Freund" [probably Walter], no date [ca May 1929], 534/5/210, 64, RGASPI.

6o Internationales Hafenbüro Hamburg, Bericht Juni 1929, 534/5/210, 65, RGASPI.

61 Internationales Hafenbüro Hamburg, Bericht Juni 1930, 534/5/216, 39, RGASPI.

62 Internationales Hafenbüro Hamburg, Bericht August 1929, 534/5/210, 83, RGASPI.

63 Internationales Hafenbüro Hamburg, Bericht Oktober 1929, 534/5/210, 98, RGASPI. 
TABLE 7 Agitation among Chinese mariners in Hamburg during spring 1930

\begin{tabular}{lll}
\hline Vessel Flag & $\begin{array}{l}\text { Chinese crew Meetings } \\
\text { (stokers) }\end{array}$ & $\begin{array}{l}\text { How many } \\
\text { came }\end{array}$ \\
\hline
\end{tabular}

\section{March 1930}

\begin{tabular}{lllll}
\hline ss Telean & NL & 30 & 1 & 6 \\
ss Ficimius & UK & 26 & 1 & 5 \\
ss Peisander & NL & 27 & & \\
ss Samarinda & NL & 31 & & \\
ss Maaskerk & NL & 30 & & \\
ss Eurymedon & UK & 20 & & $5+3$ \\
ss Drechtland & NL & 28 & 2 & \\
ss Ouderkerk & NL & 27 & & \\
ss Blitar & NL & 12 & & \\
\hline
\end{tabular}

\section{April 1930}

$\begin{array}{lllll}\text { ss Poelean Bras } & \text { NL } & 27 & & \\ \text { ss Bendaran } & \text { UK } & 28 & 2 & 6+5 \\ \text { ss Oldenburg } & \text { German } & 28 & & \\ \text { ss Cherry Beach } & \text { UK } & 27 & 2 & \text { [not stated] } \\ \text { ss Havenstein } & \text { German } & 25 & & \\ \text { "Oel-dampfer" [tanker] } & \text { UK } & 26 & & \\ \text { ss Gripselain } & \text { NL } & 27 & & \\ \text { ss Peisander } & \text { NL } & 25 & & 3 \\ \text { ss Niaas } & \text { NL } & 28 & 1 & \\ \text { ss Rifronten } & \text { NL } & 27 & & \\ \text { ss Ouderkerk } & \text { NL } & 27 & & \end{array}$

SOURCE: BERICHT ÜBER DIE ARBEIT UNTER DEN CHINESISCHEN SEELEUTEN, 1-31.3.1930 \& 3-28.4.1930, 534/5/216, 36-37, RGASPI

between China and various European ports. ${ }^{64}$ His main tool was the Chinese ship magazine, the 'Chinese Seamen', which he edited and had published

64 Annual Report of the Hamburg Interclub for 1930, 534/5/216, 77-81, RGASPI. On Liao Chenghzi, see Gregor Benton, Chinese Migrants and Internationalism. Forgotten histories 1917-1945 (Abingdon: Routledge, 2007), 55. 
several issues already by the end of the year. ${ }^{65}$ The Interclub, probably through Liao Chenghzi, engaged a Chinese mariner in early 1930, and the two agitators commenced in laying the foundations of the extra-territorial network of the Chinese Seamen's Union in Europe. ${ }^{66}$ The two mainly engaged with Chinese crews on board British and Dutch vessels, see Table 7.

Liao Chengzhi systematically distributed Chinese papers and literature among Chinese mariners, including 'The Red Flag', 'The Worker' and other pamphlets of the red All China Workers Federation that were sent directly to him three times a month. The two agitators were in most cases only capable of approaching the Chinese crews on board the steamers, only a few of them attended the seven meeting they arranged at the Interclub in March and April 1930. However, it seems as if Liao Chenghzi had managed to establish a sea cell on board the SS Ouderkerk. Sometimes, he distributed papers to crew members on land as was the case with the SS Tirpitz of the Hamburg America Line (HAPAG). Another case was the British tanker whose 27 Chinese stokers came ashore and stayed in a hotel where Liao Chenghzi was capable to interact with them. A special case was the Japanese steamer Atlas Maru who listed a crew of 6o members (it is unclear in Liao's report how many of them were Chinese); Liao managed to arrange four meetings for the crew. In total, five (probably Chinese) stokers and one (probably Chinese) cook attended the meetings, and Liao euphorically noted that he had succeeded in organising a ship committee. Also, he enlisted two young Chinese workers who were willing to help him in agitation in the lodgements of the "Seamen's Quarter" at Schmuckstrasse in the S:t Pauli area, the site of Hamburg's Chinatown. ${ }^{67}$

65 Internationales Hafenbüro Hamburg, Bericht November 1929, 534/5/210, 101, RGASPI; Internationales Hafenbüro Hamburg, Jahresbericht für 1929, 534/5/210, 107, RGASPI.

66 Internationales Hafenbüro Hamburg, Bericht Januar 1930, 534/5/216, 11, RGASPI. A similar network was already in the making in South East Asia where Chinese communists infiltrated and dominated seamen's associations and unions in, e.g., Malaysia and Singapore, whose membership predominantly constituted of Chinese emigrants and diaspora groups. See further Anna Belogurova, "The Chinese International of Nationalities: The Chinese Communist Party, the Comintern, and the foundation of the Malayan National Communist Party, 1923-1939," Journal of Global History 9, no. 3 (2014): 447-470; Anna Belogurova, The Nanyang Revolution: The Comintern and Chinese Networks in Southeast Asia, 1890-1957 (Cambridge: Cambridge University Press, 2019).

67 Bericht über die Arbeit unter den chinesischen Seeleuten, 1-31.3.193o \& 3-28.4.1930, 534/ 5/216, 36-37, RGASPI. On Hamburg's Chinatown, see Lars Amenda, Fremde, Hafen, Stadt: Chinesische Migration und ihre Wahrnehmung in Hamburg 1897-1972 (München: Dölling und Galitz, 2006), and Lars Amenda, "Metropole, Migration, Imagination: Chinesenviertel und chinesische Gastronomie in Westeuropa 1900-1970," Zeithistorische Forschungen/ Studies in Contemporary History 4 (2007): 287-310; also Susann Witt-Stahl, Das vergessene 
Chinatown: Die Schmuckstrasse auf St. Pauli (6.4.2020), https://www.shz.de/regionales/hamburg/das-vergessene-chinatown-die-schmuckstrasse-auf-st-pauli-id27944002. html (checked 29.4.2020). See further Lars Amenda, "Between Southern China and the North Sea: Maritime Labour and Chinese Migration in Continental Europe, 189o-1950," in Asian Migrants in Europe: Transcultural Connections, eds. Sylvia Hahn and Stan Nadel (Göttingen: V\&R Unipress, 2014), 59-8o. 